ИЗВЕСТИЯ АКАДЕМИИ НАУК ЭСТОНСКОН ССР. ТОМ ХІІІ

СЕРІЯ ФИЗИКО-МАТЕМАТІЧЕСКИХ И ТЕХНИЧЕСКИХ НАУК, 1964, № 4

\title{
ИЗОМЕРИЗАЦИЯ ОЛЕФИНОВЫХ УГЛЕВОДОРОДОВ ПРИ ХРОМАТОГРАФИРОВАНИИ НА СИЛИКАГЕЛЕ
}

\author{
О. ЭЙЗЕН, \\ кандидат технических наук \\ Л. КУДРЯВЦЕВА, С. РАНГ, \\ кандидаты химических наук
}

Исследование химического состава продуктов термического крекинга парафинов Фишера-Тропша, нефти и бурого угля показало, что присутствующие в них олефины представлены преимущественно 1-олефинами $[1,2]$. Перемещение двойной связи олефинов вдоль всей углеродной цепи приводит к равновссию между всеми теоретически возможными изомерами двойной связи данного олефина [3]. Присутствие в продуктах крекинга преимущественно 1 -олефинов объясняется ложным (заторможенным) равновесием. Действие факторов (изменение температуры, катализаторы), выводящих из состояния ложного равновесия, приводит к сбразованию других возможных изомеров двойной связи.

Анализ олефиновых углеводородов сланцевой смолы устанавливает наличие 1-, 2- и 3-изомеров [4,5]. При количественном определении состава олефинов следует учитывать возможность протекания процессов, направленных на достижение состояния истинного равновесия, а также на его смещение под влиянием различных факторов.

Выделение олефиновых углеводородов из сложных органических смесей осуществляется обычно хроматографированием на силикагеле. Изучение состава олефинов при этом усложняется полимеризацией и значительными потерями. Қак показали исследования А. В. Топчиева и сотрудников $\left[{ }^{6}\right]$, указанных трудностей можно избежать путем соответствующей предварительной обработки силикагеля и проведения хроматографирования при низкой температуре (близкой к $0^{\circ} \mathrm{C}$ ). При обработке силикагеля особое внимание уделяется очистке его от примесей железа и органических соединений, а также промыванию до нейтральной реакции.

Подробные количественные данные об изомеризации двойной связи, а также о поведении олефинов с различной структурой при хроматографическом анализе в литературе отсутствуют $\left[{ }^{9}, 10\right]$.

Цель настоящей работы заключалась в том, чтобы восполнить в известной мере этот пробел. В ней приводятся некоторые данные об изомеризации олефиновых углеводородов при хроматографировании на силикагеле.

\section{Экспериментальная часть}

Р е акти вы. Характеристика степени чистоты исследованных олефиновых углеводородов приведена в табл. 1.

Адсорбенты. В качестве адсорбентов применялись силикагели марок АCM, KCM и КСК с величиной зерен 150-200 меш в необрабо- 
Таблициа 1

Характеристика олефинов, использованных в работе *

\begin{tabular}{|c|c|c|}
\hline $\begin{array}{l}\text { № } \\
\text { пा. }\end{array}$ & $\begin{array}{c}\text { Название } \\
\text { углеводорода }\end{array}$ & $\begin{array}{l}\text { Чистота (в \%), определен- } \\
\text { ная методом газо-жидкост- } \\
\text { ной хроматографии и ин- } \\
\text { фракрасной спектроскопии }\end{array}$ \\
\hline $\begin{array}{l}6 . \\
7 . \\
8 . \\
9 .\end{array}$ & $\begin{array}{l}\text { Гексен-1 } \\
\text { Гептен-1 } \\
\text { Гептен-2 } \\
\text { Октен-1 } \\
\text { Октен-2 } \\
\text { Нонен-1 } \\
\text { Додецен-1 } \\
\text { Гексадецен-1 } \\
2 \text {-Әтилгексен-1 } \\
2,5 \text {-Диметил-2,4-гекса- } \\
\text { диен } \\
2,6-\text { Диметилгептен-1 } \\
\text { 1-Пропилциклогек- } \\
\text { сен-1 }\end{array}$ & $\begin{array}{l}\text { Более } 99 \% \text { 1-изомера } \\
\text { Более 99\% цис-изомера } \\
45,1 \% \text { транс-изомера; } 54,9 \% \\
\text { цис-изомера } \\
\text { Степень чистоты более } 99 \% \\
47,4 \% \text { транс-изомера; } 52,6 \% \\
\text { цис-изомера } \\
\text { Степень чистоты более } 99 \% \\
\text { Более } 99 \% \quad 1 \text {-изомера } \\
\text { Степень чистоты более } 99 \% \\
\text { Более } 99 \% \text { 1-изомера } \\
\text { - - } \\
\text { 7,0\% 2,6-диметилгептена-2 } \\
\text { Степень чистоты более } \\
99,5 \%\end{array}$ \\
\hline
\end{tabular}

* Все нспользованные олефины являются импорт ными, за исключением пропилциклогексена, синтезированного в нашей лаборатории.

танном и обработанном виде [ $\left.{ }^{6}\right]$. Активность силикагелей, определенная по бензолу [7], равнялась для АСM - 12, для $\mathrm{KCM}-10$ и для $\mathrm{KCK}-7$. Силикагели сушили 6 ч при температуре $60^{\circ}$ и 24 и при температуpe $150^{\circ}$.

\section{Методика исследования}

a) При хроматографировании методом вытеснения применялись трехсекционные колонки с охладительной муфтой [ $\left.{ }^{6}\right]$. Температура воды в муфте была $6^{\circ}$. Продолжительность пребывания смеси в колонке составляла $6-8$. В каждом опыте отбирались в калибрированные приемники 12-20 фракций. Пробы взвешивались и анализировались газохроматографическим методом.

б) При хроматографировании элюентным методом применялись колонки длиной 2,4 м, с поперечным сечением 22 мм. Вымывание парафинов осуществлялось петролейным эфиром (пределы кипения $40 \div 60^{\circ}$ ), арсматических углеводородов - бензолом, кислородных соединений ацетоном или этанолом.

Из полученных растворов перегонкой и пробулькиванием осветительного газа удаляли растворитель (элюент), остаток взвешивали и анализировали газохроматографически.

в) Для проведения опытов по изучению изомеризации олефинов применялись стеклянные колонки длиной 280 мм, диаметром 10 мм и вместимостью 12-17 г силикагеля. Қолонки были снабжены охладительными муфтами.

В наполненную силикагелем колонку наливали исследуемый олефин в количестве, пропорциональном активности силикагеля. „По истечению определенного времени олефин вытесняли из колонки этанолом и отбираемые фракции анализировали газохроматографическим методом. 
Во всех исследованиях ( $a$, б и в) фракции, содержавшие олефины, дополнительно анализировались методом инфракрасной спектроскопии на приборе ИКС-14 (по характерным для олефинов максимумам 910 , 970 и $\left.990 \mathrm{~cm}^{-1}\right)$.

Газохром атографический ан ализ. Для анализа применялся газохроматограф УХ-1 с катарометром. Характеристика наполнителей колонок приведена в табл. 2.

Таблица 2

Характеристика колонок, использованных в газохроматографическом анализе

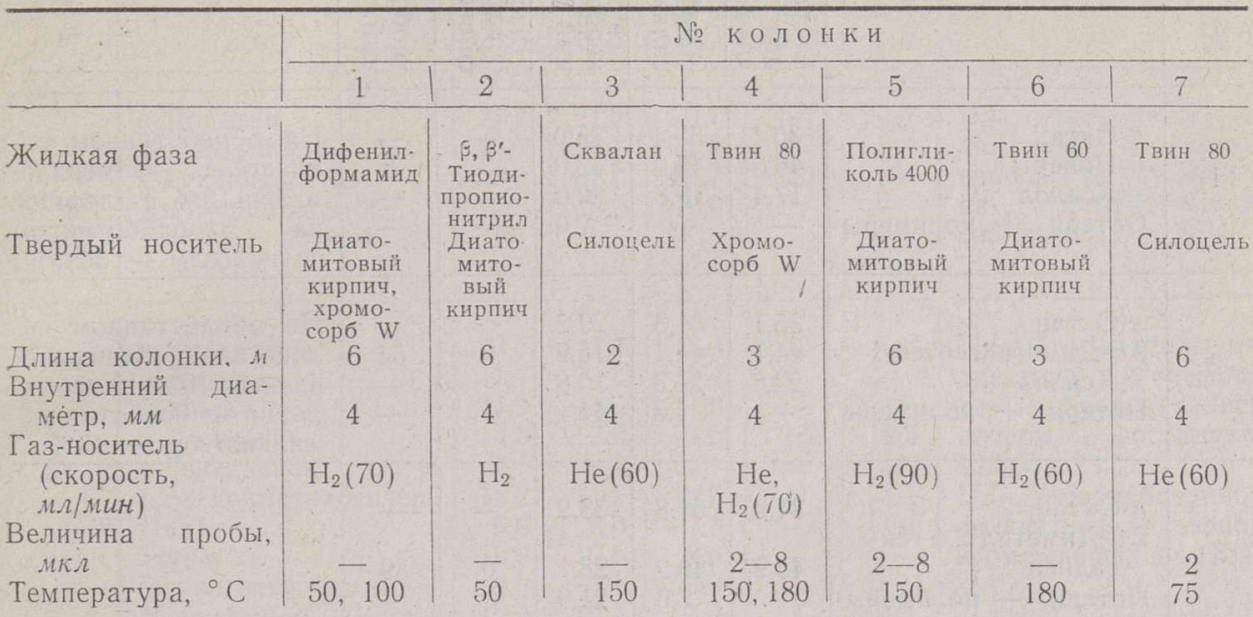

Во всех опытах потери определялись при хроматографировании на силикагеле по данным газохроматографического анализа. Количества отдельных компонентов в отобранных фракциях суммировались и сравнивались с их исходными количествами.

\section{Результаты эксперимента}

Первая серия опытов по определению изомеризующей и полимеризующей способности силикагелей была поставлена в условиях, по возможности более близких к условиям анализа фракций сланцевой смолы. В связи с этим составлялись искусственные смеси, содержавшие помимо олефиновых углеводородов также парафиновые и ароматические углеводороды и кислородные соединения.

В табл. 3 приведены результаты хроматографирования методом вытеснения трех смесей на обработанном и необработанном силикагелях KCM.

Результаты хроматографирования элюентным методом искусственных смесей № 4 и 5, исследованных соответственно на обработанном и необработанном силикагелях КСМ и АСM, приведены в табл. 4.

Последние графы в табл. 3 и 4 содержат данные об изомеризации олефиновых углеводородов при хроматографировании.

На примере двух нормальных олефинов гексена-1 и додецена-1 изучалось перемещение двойной связи при хроматографировании на силикагелях трех марок АСM, КСМ и КСК в течение 4 и 48 ч. Результаты этих опытов приведены в табл. 5. 
Изомеризация олефиновых углеводородов при хроматографировании на силикагеле методом вытеснения *

\begin{tabular}{|c|c|c|c|c|c|c|c|}
\hline \multirow[b]{2}{*}{ 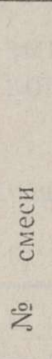 } & \multirow[b]{2}{*}{$\begin{array}{c}\text { Компоненты } \\
\text { смеси }\end{array}$} & \multirow{2}{*}{ 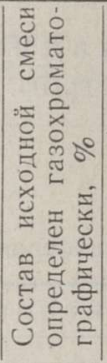 } & \multicolumn{2}{|c|}{$\begin{array}{l}\text { Состав сме- } \\
\text { си после хро- } \\
\text { матографи- } \\
\text { рования, \% }\end{array}$} & \multicolumn{2}{|c|}{$\begin{array}{c}\text { Потери оле- } \\
\text { финов, \% }\end{array}$} & \multirow[b]{2}{*}{ Примечания } \\
\hline & & & 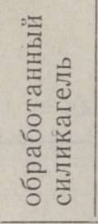 & 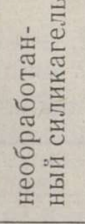 & 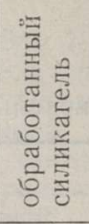 & 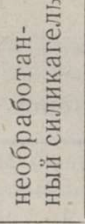 & \\
\hline 1 & $\begin{array}{l}\text { H-Октан } \\
\text { H-Нонен-1 } \\
\text { M-Ксилол } \\
\text { Потери + полимеры }\end{array}$ & $\begin{array}{l}36,1 \\
46,5 \\
17,4 \\
-\end{array}$ & $\begin{array}{l}35,4 \\
45,0 \\
19,8 \\
-\end{array}$ & $\begin{array}{r}35.0 \\
43,0 \\
20,0 \\
2,0\end{array}$ & $\frac{\overline{3}}{-}$ & $\frac{\overline{8}}{-}$ & $\begin{array}{l}\text { На обработанном си- } \\
\text { ликагеле изомеризо- } \\
\text { валось } 3 \% \text { 1-олефина, } \\
\text { на необработанном } \\
\text { силикагеле }-30 \%\end{array}$ \\
\hline 2 & $\begin{array}{l}\text {-Октан } \\
2,6 \text {-Диметилгептен-1 } \\
\text { м-Ксилол } \\
\text { Нотери + полимеры }\end{array}$ & $\begin{array}{l}35,1 \\
44,1 \\
20,8 \\
\end{array}$ & $\begin{array}{r}31,3 \\
44,1 \\
21,3 \\
1,3\end{array}$ & $\begin{array}{l}29,2 \\
15,9 \\
10,8 \\
44,1\end{array}$ & $\overline{0}$ & $\begin{array}{l}\overline{64} \\
\overline{-}\end{array}$ & $\begin{array}{l}\text { На обработанном си- } \\
\text { ликагеле изомеризо- } \\
\text { валось } 10 \% \text { 1-изоме- } \\
\text { ра, на необработанном } \\
\text { силикагеле }-43 \%\end{array}$ \\
\hline 3 & $\begin{array}{l}\text { H-Октан } \\
2,6 \text {-Диметил-2,4-гек- } \\
\text { садиен } \\
\text { Потери }+ \text { полимеры }\end{array}$ & $\begin{array}{l}34,6 \\
45,9\end{array}$ & $\begin{array}{r}31,8 \\
46,2 \\
2,6\end{array}$ & $\begin{array}{l}33,2 \\
28,1 \\
21,9\end{array}$ & $\begin{array}{l}- \\
0 \\
-\end{array}$ & $\begin{array}{l}- \\
39\end{array}$ & - \\
\hline
\end{tabular}

* Силикагель марки КСМ, весовое соптношение смеси и силикагеля - $1: 13$, температура $6^{\circ}$, вытеснитель - этанол.

Данные табл. 6 иллюстрируют зависимость степени изомеризации от структуры олефинов при хроматографировании на обработанном и необработанном силикагелях АCM.

Помимо этого изучалась зависимость изомеризации гексена-1 от продолжительностй опыта при хроматографировании на обработанном и необработанном силикагелях $\mathrm{ACM}$ (табл. 7) и от температуры опыта при хроматографировании (табл. 8) на необработанном силикагеле АСM. Результаты этих исследований изображены на рис. 1 и 2.

\section{Обсуждение результатов}

Хроматографирование вытеснительным и элюентным методами, проводимое в условиях, близких к хроматографированию крекингбензинов, было осуществлено с целью проверки надежности данных о групповом составе олефинов, а также данных о содержании в бензинах 1 -олефинов с учетом возможности их превращения в 2- и 3-олефины.

Помимо указанной цели была поставлена задача более полно вскрыть и уточнить действне выявленных в вышеуказанных исследованиях факторов, влияющих на процесс изомеризации олефинов при хроматографировании их на силикагеле.

Многочисленные факторы, влияющне на результат хроматографирования олефинов, в том числе и на процесс изомеризации при хромато- 
Результаты хроматографирования элюентным методом

\begin{tabular}{|c|c|c|c|c|c|c|c|}
\hline \multirow[b]{2}{*}{ 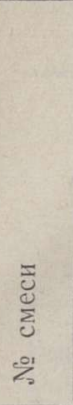 } & \multirow[b]{2}{*}{ Компоненты смеси } & \multirow{2}{*}{ 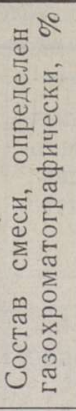 } & \multicolumn{2}{|c|}{$\begin{array}{l}\text { Состав } \\
\text { смеси после } \\
\text { хромато- } \\
\text { графиро- } \\
\text { вания, \% }\end{array}$} & \multicolumn{2}{|c|}{$\begin{array}{c}\text { Потери } \\
\text { олефинов, \% }\end{array}$} & \multirow[b]{2}{*}{ Примечания } \\
\hline & & & 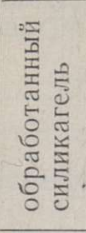 & 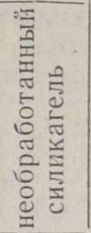 & 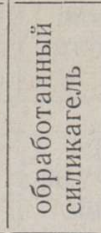 & 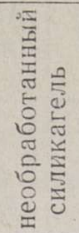 & \\
\hline $4 *$ & $\begin{array}{l}\text { н-Додекан } \\
\text { Изоамилбензол } \\
\text { н-Гексадецен-1 } \\
\text { Ди-н-пропилкетон } \\
\text { Примеси, потери, по- } \\
\quad \text { лимеры }\end{array}$ & $\begin{array}{r}21,7 \\
25,7 \\
38,9 \\
10,5 \\
3,2\end{array}$ & $\begin{array}{r}21,0 \\
24,1 \\
38,0 \\
10,5 \\
5,5\end{array}$ & $\begin{array}{l}20,7 \\
18,8 \\
32,7 \\
10,0 \\
17,8\end{array}$ & $\bar{z}$ & $\overline{-}$ & $\begin{array}{l}\text { На обработанном си- } \\
\text { ликагеле изомеризо- } \\
\text { валось } 1 \% \text { олефина-1, } \\
\text { на необработанном } \\
\text { силикагеле - } 99 \%\end{array}$ \\
\hline $5 * *$ & $\begin{array}{l}\text { н-Ундекан } \\
\text {-Додекан } \\
\text { Декалин } \\
\text { H-Додецен-1 } \\
\text {-Гексадецен-1 } \\
1,2,3 \text {-Триметилбензол } \\
\text { Индан } \\
\text { Тетралин } \\
\text { Метилгептилкетон } \\
\text { Ацетофенон }\end{array}$ & $\begin{array}{r}13,7 \\
13,7 \\
11.9 \\
4,0 \\
4,1 \\
12,2 \\
9,0 \\
10,9 \\
3,2 \\
12,9\end{array}$ & $\begin{array}{r}13,4 \\
13,7 \\
11,5 \\
3,9 \\
4,1 \\
11,2 \\
3,0 \\
10,5 \\
3,1 \\
12,7\end{array}$ & $\begin{array}{r}13,4 \\
13,4 \\
11,9 \\
3,5 \\
4,1 \\
10,9 \\
7,8 \\
9,6 \\
3,0 \\
3,0\end{array}$ & $\begin{array}{l}- \\
\overline{-} \\
2,5 \\
\overline{-} \\
\overline{-} \\
- \\
-\end{array}$ & $\begin{array}{l}\overline{-} \\
\overline{12,5} \\
\overline{-} \\
\overline{-} \\
\overline{-}\end{array}$ & $\begin{array}{l}\text { На обработанном си } \\
\text { ликагеле 1-олефины } \\
\text { не изомеризовались } \\
\text { потери составлял } \\
12,5 \% \text {. } \\
\text { На необработанном } \\
\text { силикагеле } 1 \text {-олефины } \\
\text { изомеризовались } 100 \%\end{array}$ \\
\hline
\end{tabular}

* Снликагель КСМ, весовое соотношение смеси и силикагеля - 1: 10, температура $18^{\circ}$.

** Силикагель АCM, весовое соотношение смеси и силикагеля - 1: 11,6, температура $18^{\circ}$.

графирований на силикагеле, мы разбили на три группы, которые были определены соответственно: 1) методикой и условиями проведения хроматографирования, 2) свойствами адсорбента, 3) структурой хроматографируемых олефинов.

Из данных опытов (см. табл. 3 и 4) следует, что при применении обработанного силикагеля потери олефинов невелики, достигая для додецена-1 лишь 2,5\%. Хроматографирование 2,6-диметилгептена-1, 2,5-диметил-2,4-гексадиена проведено без потерь. При применении необработанного силикагеля потери были особенно велики в случае названных выше соединений. Олефины образуют со спиртом неотделимый. от силикагеля слой полимера. Из данных табл. 3 видно, что олефины нормальной структуры изомеризуются заметно меньше, чем изоолефины. Данные таб́л. 6 подтверждают этот вывод. Особенно активно изомеризуется на силикагеле АСM 2-этилгексен-1, причем степень изомеризации не зависит практически от обработки силикагеля. В течение 24 ч 50\% исходного изоолефина-1 превращается в изоолефин-2. В то же время степень изомеризации 2,6-диметилгептена-1 сильно зависит от обработки силикагеля. При хроматографировании на обработанном силикагеле изомеризации не наблюдается, тогда как при применении необработанного силикагеля 2,6-диметилгептен-1 изомеризуется практи- 
Изомеризация гексена-1 и додецена-1 на необработанных силикагелях марок АСМ, КСМ и КСК

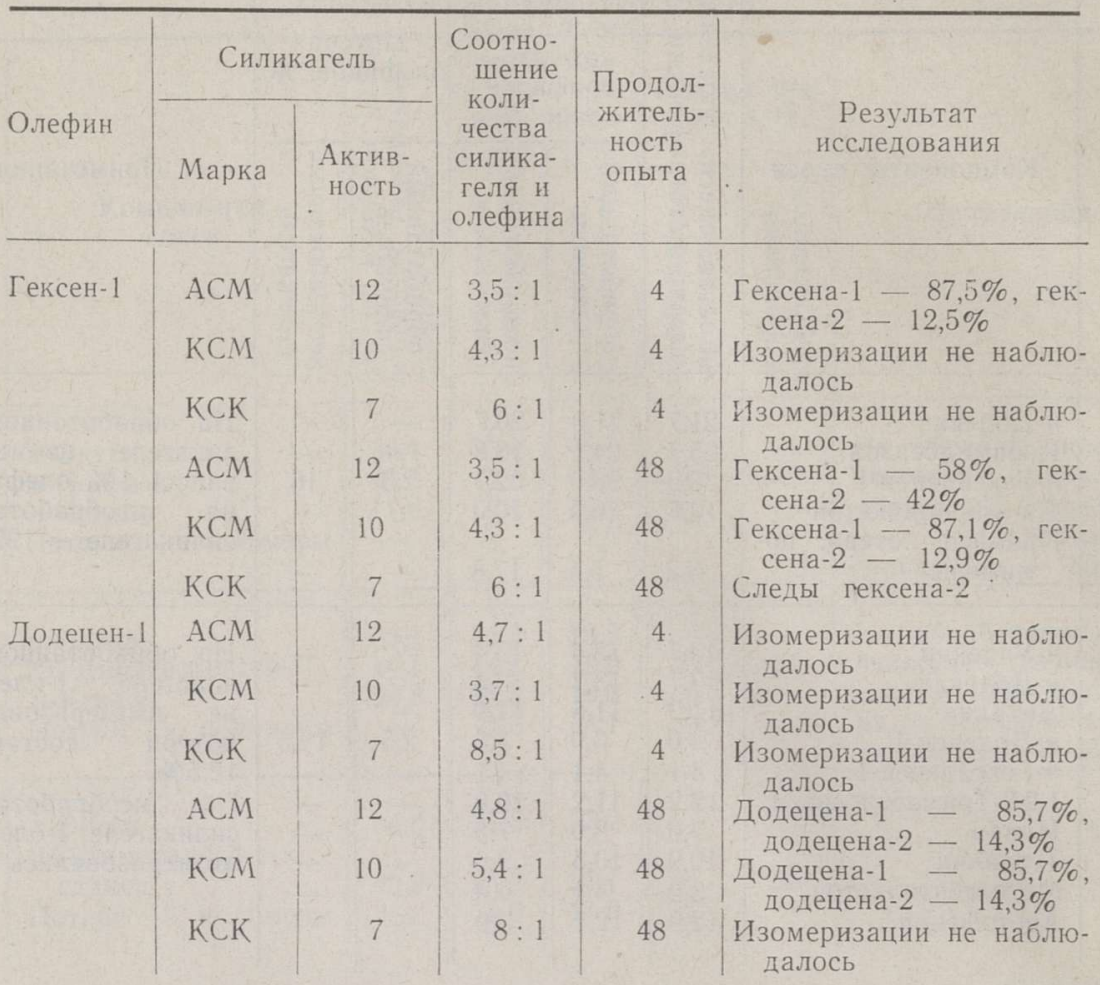

чески полностью. Не меняется расположение двойной связи на необработанном силикагеле и в молекуле пропилциклогексена-1. Однако указанный циклоолефиі сильно полимеризуется на необработанном силикагеле.

Для 2-олефинов характерно изменение соотношения транс- и цисизомеров, особенно сильно оно проявляется при хроматографировании на необработанном силикагеле. Әто соотношение изменяется в сторону увеличения содержания цис-изомера. Исследование хроматографирования 2 -гептена (цис-изомера $54,9 \%$ и транс-изомера $45,1 \%$ ) на обработанном силикагеле показало, что соотношение изомеров на нем изменилось до 36,5\% транс-изомера.

При хроматографировании на необработанном силикагеле при температуре $6^{\circ}$ изомеризация 1-олефинов составляет $30-43 \%$. Изомеризация на обработанном силикагеле примерно в $3-4$ раза меньше.

Хроматографирование элюентным методом осуществлялось на силикагелях марки КСМ и АСM (см. табл, 4). Из данных табл. 4 следует, что большие потери олефинов наблюдаются в случае применения необработанных силикагелей. На указанных силикагелях степень изомери зации 1-олефинов достигает практически 100\% (гексадецен-1 и додепен-1), в то время как на необработанных силикагелях изомеризация незначительна.

Результаты этих исследований согласуются с данными табл. 6. При хроматографировании олефннов различной структуры большая степень изомеризации наблюдается при применении необработан- 


\section{Изомеризация олефинов различной структуры на обработанном и необработанном силикагелях АСМ (активность 12), при продолжительности опыта 24 ч}

\begin{tabular}{|c|c|c|c|}
\hline Олефин & $\begin{array}{c}\text { Весовое } \\
\text { соотно- } \\
\text { шение } \\
\text { силика- } \\
\text { геля и } \\
\text { олефина }\end{array}$ & $\begin{array}{c}\text { Силикагель } \\
\text { АСМ }\end{array}$ & Результаты \\
\hline 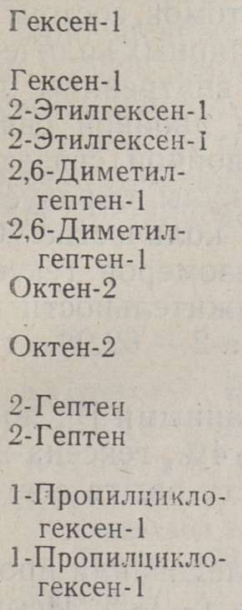 & $\begin{array}{l}6,3: 1 \\
5,6: 1\end{array}$ & $\begin{array}{l}\text { Обработанный } \\
\text { Необработанный } \\
\text { Обработанный } \\
\text { Необработанный } \\
\text { Обработанный } \\
\text { Необработанный } \\
\text { Обработанный } \\
\text { Необработанный } \\
\text { Обработанный } \\
\text { Необработанный } \\
\text { Обработанный } \\
\text { Необработанный }\end{array}$ & 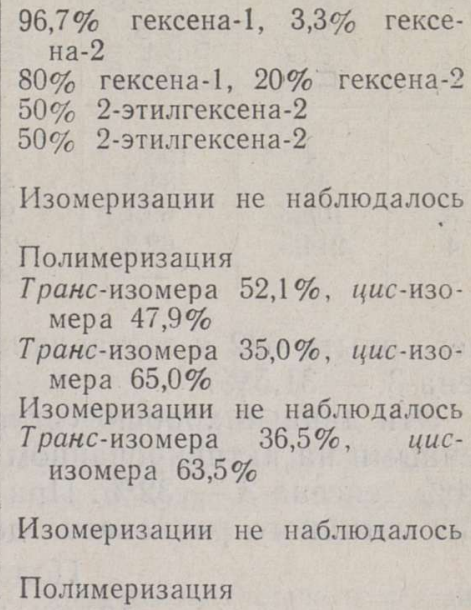 \\
\hline
\end{tabular}

ного силикагеля. Указанная на рис. 2 зависимость изомеризации гексена-1 от продолжительности опыта также подтверждает вышесказанное.

Приведенные в табл. 5 данные характеризуют зависимость степени изомеризации гексена-1 и додецена-1 от марки необработанного силикагеля (активности), количества адсорбента и продолжительности опыта (времени контактирования). Из приведенных , данных следует, что наиболее сильным изомеризующим действием обладает силикагель марки АCM, имеющий наибольшую активность. Опыт проводился при условии постоянства произведения количества определенной

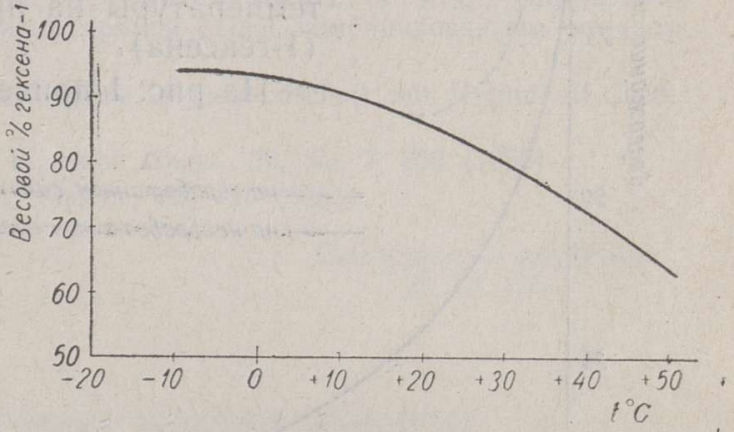

Рис. 1. Изомеризация гексена-1 на необработанном силикагеле в зависимости от температуры (продолжительность опыта 4 ч). марки силикагеля на его активность. Данные, приведенные в табл. 5 , указывают на большую инертность молекулы додецена-1 к процессу изомеризации по сравнению с молекулой гексена-1. Одновременно с этим данные табл. 5 позволяют сделать вывод о сильном влиянии продолжительности опыта (времени контактирования) на процесс изомеризации. Так, для гексена-1 увеличение времени контактирования на силикагеле $\mathrm{ACM}$ с 4 до 48 ч увеличивает степень изомеризации до $29,5 \%$, для додецена до 14,3\%. Әтот вывод подтверждается также данными рис. 2. 
Таблица 7

Данные по изомеризации гексена-1 на силикагеле АСМ при различной продолжительности хроматографирования

\begin{tabular}{|c|c|c|c|c|}
\hline \multirow[b]{2}{*}{$\begin{array}{l}\frac{\pi}{3} \\
\frac{3}{0} \\
\frac{0}{b}\end{array}$} & \multicolumn{2}{|c|}{$\begin{array}{c}\text { Обработанный } \\
\text { силикагель }\end{array}$} & \multicolumn{2}{|c|}{$\begin{array}{c}\text { Необработанный } \\
\text { силикагель }\end{array}$} \\
\hline & 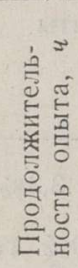 & 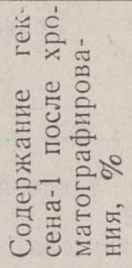 & 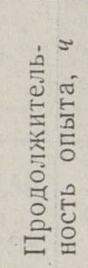 & 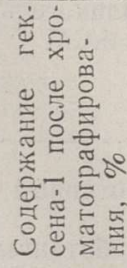 \\
\hline $\begin{array}{l}1 \\
2 \\
3 . \\
4 \\
5\end{array}$ & $\begin{array}{c}4 \\
48 \\
100,3 \\
214,5 \\
-\end{array}$ & $\begin{array}{l}100 \\
84,3 \\
69,1 \\
62,3 \\
-\end{array}$ & $\begin{array}{r}4 \\
49 \\
99 \\
213 \\
692\end{array}$ & $\begin{array}{r}87,5 \\
57,2 \\
42,2 \\
25,3 \\
5,6\end{array}$ \\
\hline
\end{tabular}

В опытах с необработанным силикагелем (продолжительность опытов 200 ч) был получен помимо гексена- 2 также и гексен-3, т. е. все три теоретически возможные изомера гексена. Согласно данным литературы [3] равновесная смесь изомеров олефинов, молекулы которых содержат четное число углеродных атомов, состоит из эквимолекулярных количеств изомеров с внутренним расположением двойной связи; изомер с двойной связью в конце молекулы образуется в меньшем количестве. Содержание изомеров гексена при продолжительности нашего опыта 692 и составляло: гексена-1 - 5,6\%, гексена- $2-62,9 \%$, гексена-3 - 31,5\%.

Эти данные хорошо согласуются с равновесными данными [8], полученными на активированном угле при $190^{\circ}:$ гексена- $1-4 \%$, гексена- $2-$ $64 \%$, гексена-3 - 32\%. При меньшей продолжительности опыта состояния истинного равновесия достигнуто не было.

Подавляющая часть наших исследований прово-

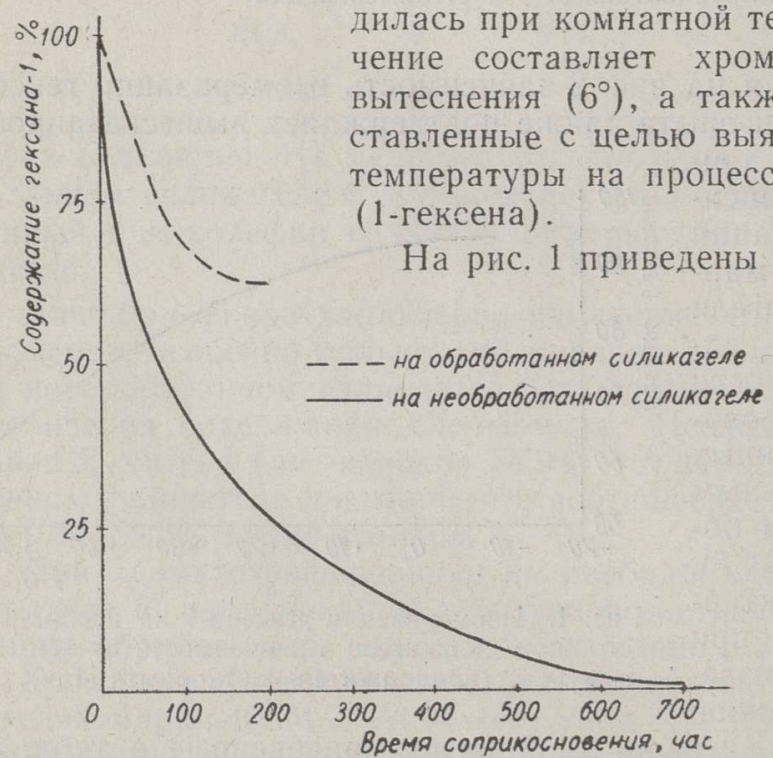

Рис. 2. Зависимость изомеризацин гексена-1 от продолжительности соприкосновения $c$ силикагелем. данные о зависнмости изомеризации гексена-1 от температуры. Плавный ход кривой этой зависнмости указывает на закономерный рост изомернзации с повышением температуры. Более высокая степень изомеризации при элюировании по сравнению с данными хроматографирования вытеснительным методом $\left(6^{\circ}\right)$ отчасти объясняется хроматографнрованием элюентным методом при более высокой температуре $\left(\sim 18^{\circ}\right)$.

Приведенные в настоя-

щей работе данные, полученные методом газовой хроматографии, дают возможность количественно оценить реакции изомеризации олефинов в зависимостн от свойств силикагеля, структуры хроматографируемых 
соединений и условий хроматографирования.

Применение газохроматографии при исследовании изомеризации олефинов позволило аналитически решить эту проблему более точно (определить количества 1-, 2-, 3-олефинов и их цис- и транс-изомеров).

Приведенные в настоящей работе данные могут служить основой для оценки точности группового анализа крекингбензинов нефти и сланцевой смолы.
Данные об изомеризации гексена-1 на силикагеле ACM при различных температурах (время 4 ч)

\begin{tabular}{|c|c|c|c|c|}
\hline \multirow{2}{*}{ 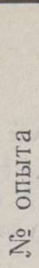 } & \multirow{2}{*}{$\begin{array}{l}0 \\
0 \\
0 \\
0 \\
0 \\
0 \\
0 \\
0 \\
0 \\
0 \\
0 \\
0\end{array}$} & \multirow{2}{*}{ 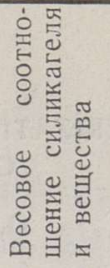 } & \multicolumn{2}{|c|}{$\begin{array}{c}\text { Содержание изоме- } \\
\text { ров после хрома- } \\
\text { тографирования, } \\
\%\end{array}$} \\
\hline & & & Гексен-1 & Гексен-2 \\
\hline $\begin{array}{l}1 \\
2 \\
3 \\
4 \\
5\end{array}$ & $\begin{array}{r}-9 \\
10 \\
18 \\
30 \\
50\end{array}$ & $\begin{array}{l:l}5,5 & : 1 \\
5 & : 1 \\
5 & : 1 \\
4 & : 1 \\
5,4 & : 1\end{array}$ & $\begin{array}{l}94,0 \\
90,3 \\
87,5 \\
80,1 \\
63,2\end{array}$ & $\begin{array}{r}6,0 \\
9,7 \\
12,5 \\
19,9 \\
36,8\end{array}$ \\
\hline
\end{tabular}

\title{
ЛИТЕРАТУРА
}

1. A s ing e r F., Ber. Dtsch. chem. Ges., 75, 656 (1942).

2. Тиличеев Д. М., Миловидова Н. В., ЖПХ, 22, 611 (1949).

3. A s inger F., Chemie und Technologie der Monoolefine, Akad. Verlag, Berlin, 1957.

4. Эй зен О: Г., Р ан г С. А., О химическом составе олефиновых углеводородов. сланцевой смолы. Горючие сланцы. Химия и технология, вып. 4, АН Эст. ССР, Таллин, 1961, стр. 200.

5. Эй зен О. Г., Р а нг С. А., $Э$ йз ен Ю. И., О химическом составе и методике анализа непредельных углеводородов лигроиновых фракщий сланцевой смолы, Изв. АН ЭССР. Сер. физ.-матем. и техн. наук, № 1, 27 (1964).

6. Топчиев А. В., Исхакова Э. Х., Мусаев И. А., ГальпернГ. Д., Химия и технология топлива, № 11, 26. (1957).

7. Л анд д берг Г. С., Ба жуллин П. А., Қ азанский Б. А. и др., Определение индивидуального состава бензиноз прямой гонки комбинированным методом, Изд. АН СССР. М., 1959.

8. Koch H. und Richter H., Öl und Kohle in Gemeinschaft mit Brennstoff-Chem., 40, 231 (1944).

9. F ink D., Lew is R. W., W e is s F., Anal. Chem., 22, No. 7, 850 (1950).

10. Koch H., R a g H. von, Brennstoff-Chemie, 32, 161 (1951).

Ннститут химии

Академии наук Эстонской ССP
Поступила в редакцию 30 IV 1964

\section{OLEFIINSETE SÜSIVESINIKE ISOMERISATSIOONIST SILIKAGEELIL KROMATOGRAFEERIMISE PUHUL}

\author{
0. Eisen, \\ tehnikateaduste kandidaat \\ L. Kudrjavtseva, S. Rang, \\ keemiateaduste kandidaadid
}

Resümee

Väljatõrjumis- ja elueerimismeetodil uuriti mitmesuguste faktorite (adsorbendi omadused, lähteolefiinide struktuur, katsetingimused) mōju $\mathrm{C}_{6}-\mathrm{C}_{16}$ olefiinide isomerisatsioonile nende kromatografeerimise puhul silikageelil. Gaasikromatograafilise ja infrapunase spektraalanalüüsiga määrati kunstlikult valmistatud lähtesegude ja kromatografeerimi- 
sel kogutud fraktsioonide koostised. Nende andmete alusel leiti 1-olefiinide isomerisatsiooni aste ja 2-olefiinide cis- ja trans-isomeeride suhte muutumine kromatografeerimisel soolhappe ja vesinikülihapendiga töödeldud ja töötlemata silikageelidel.
Eesti NSV Teaduste Akadeemia. Keemia Instituut
Saabus toimetusse
30. IV 1964

\title{
ISOMERIZATION OF OLEFINS BY LIQUID ADSORPTION CHROMATOGRAPHY ON SILICAGEL
}

\author{
O. Eisen, L. Kudryavtseva, S. Rang
}

\section{Summary}

The influence of various factors (properties of the adsorbent, structure of olefins, experimenting conditions) on the isomerization of $n-C_{6}-C_{16}$ mono-olefins during their adsorption chromatography on silicagel by effluent and deveiopment methods has been studied. The composition of chromatographic fractions was determined by gas-liquid chromatography and infrared spectroscopy. The quantitative side of isomerization of $\mathrm{n}-1$-mono-olefins and the change in relationship of cis-trans olefins during chromatographic adsorption analysis were estimated.

Academy of Sciences of the Estonian S.S.R., Received Institute of Chemistry 